\title{
INTRODUÇÃO DE LEGUMINOSAS FORRAGEIRAS EM ÁREAS DEGRADADAS EM PROPRIEDADES FAMILIARES DO P.A. BELO HORIZONTE
}

\author{
Priscila Duarte Malanski ${ }^{1}$; Laura Angélica Ferreira ${ }^{2}$ \\ ${ }^{1}$ Discente do curso de Agronomia, Faculdade de Ciências Agrárias de Marabá (FCAM), Universidade Federal do Pará \\ (UFPA), Marabá, Pará. BolsistaCNPq-Brasil. E-mail: priurashima@ hotmail.com. \\ ${ }^{2}$ Prof. ${ }^{a}$, D.Sc., UFPA. Email: laurange@ufpa.br.
}

RESUMO: A atividade pecuária é desenvolvida há pelo menos 20 anos no Projeto de Assentamento Belo Horizonte, localizado na área rural do município de São Domingos do Araguaia-PA. O resultado gerado por este longo tempo de exploração baseado em um manejo inadequado das pastagens é a degradação das áreas utilizadas que podem então ser abandonadas pelo agricultor para regeneração natural da vegetação ou passar por processo de reforma utilizandose da mecanização ou do fogo, seguido ou não pelo plantio de gramínea. Neste contexto, o "Projeto Promover Inovações para o Fortalecimento da Agricultura Familiar em Assentamentos do Sudeste do Pará", sob os princípios da agroecologia, propõe a introdução de espécies leguminosas forrageiras como alternativa para viabilizar o uso destas áreas e incrementar a dieta protéica do rebanho bovino. Esta alternativa será implantada com o formato de ação-teste em propriedades indicadas pela comunidade que atendam a critérios como disponibilidade de área, mão-de-obra e tempo. Para o preparo da área, será feito roço de foice e capina. No caso da puerária, será provocada a quebra de dormência das sementes através do método de imersão em água em temperatura ambiente por 12 horas. Serão formados grupos de famílias com as seguintes características: Família A: plantio de $1,5 \mathrm{~kg}$ de sementes de puerária será efetuado com plantadeira a profundidade média de e 4 $\mathrm{cm}$, em área de $1.500 \mathrm{~m}^{2}$ com espaçamento de $40 \mathrm{~cm} \mathrm{X} 40 \mathrm{~cm} ;$ Família B: plantio a lanço de $0,8 \mathrm{~kg}$ de sementes de puerária feito em área de $800 \mathrm{~m}^{2}$; Para o amendoim forrageiro, as mudas serão plantadas em covas, com espaçamento de $50 \mathrm{~cm}$ entre mudas e $50 \mathrm{~cm}$ entre linhas, em área de $387 \mathrm{~m}^{2}$; Família C: o plantio das mudas de amendoim forrageiro será feito em covas, em uma área de $400 \mathrm{~m}^{2}$ em consórcio com bananeiras já estabelecidas, respeitando o espaçamento de $50 \mathrm{~cm}$ entre mudas e $50 \mathrm{~cm}$ entre linhas. Será feito acompanhamento das ações-teste através de visitas técnicas, realizadas em intervalos de 25 dias no espaço de tempo compreendido entre o plantio e o fim do período de crescimento vegetativo. Para cada ação-teste serão escolhidas aleatoriamente três amostras de referência, que serão acompanhadas para coleta de dados quantitativos. Os dados qualitativos serão expressos em porcentagem de ocupação da área entre as leguminosas e invasoras e solo descoberto; e da descrição do estádio fisiológico, presença de pragas e/ou doenças definindo o grau de severidade do ataque, caso exista. Tais parâmetros serão tomados como critérios de avaliação do crescimento e desenvolvimento das leguminosas forrageiras em condições de campo. Nas visitas, deve-se fazer registro fotográfico da açãoteste e tomar ciência das considerações dos agricultores, assim como das suas observações realizadas. Espera-se: i) Bom crescimento e desenvolvimento das espécies leguminosas forrageiras sob condições de campo; ii) Proteção do solo contra processos erosivos hídricos e eólicos, bem como da exposição direta ao sol; iii) Diminuir a proporção de espécies invasoras da área; iv) Melhorar as propriedades químicas, físicas e biológicas do solo; vii) Viabilizar a utilização de áreas degradadas; viii) Uso das leguminosas forrageiras como fonte de proteínas na dieta do rebanho bovino.

PALAVRAS-CHAVE: Pastagem, degradação, reforma, ação-teste. 